\title{
Insolvency and financial health prediction model for the listed companies on the Indonesia Stock Exchange
}

\author{
Khaira Amalia Fachrudin* \\ Faculty of Economics and Business, Universitas Sumatera Utara, Medan, Indonesia. \\ *corresponding author email: khaira@usu.ac.id
}

\section{A R T I C L E I N F O}

Article history:

Available online

Keywords:

Insolvency, financial health,

financial distress, leverage

DOI:

https://doi.org/10.20885/jaai.vol25.i

ss1.art3

\section{A B S T R A C T}

An insolvency and financial health prediction model is an important warning to decisionmakers. This study aims to design a model that provides numbers and ranges for prediction of company insolvency and financial health. The study population is all the listed companies on the Indonesia Stock Exchange, while the sample consists of 216 companies that had negative equity from 2010 to 2019 and 216 companies with positive equity. The independent variables include the solvency and profitability ratios in one and two years before the insolvency. Logistic regression was used as an analysis tool. The results are 24 prediction models. The comprehensive one revealing the solvency ratio in the previous one year and the profitability ratio in the previous one and two years can predict the probability of insolvency and financial health.

\section{Introduction}

Insolvency refers to a company's inability to pay its obligations by due date and it limits the sustainability (Rochon et al., 2017). It is a type of financial distress indicated by negative equity. Insolvency can also be reflected by economic and business failure and bankruptcy. Corporate insolvency risk is the company's probability of becoming insolvent in the next 12 months (Baxter et al., 2007). Insolvency risk is a characteristic for all companies with no financial means to settle obligations to suppliers, shareholders, employees, creditors, government, and other entities (Obradović et al., 2018).

Insolvency and financial health predictions are very important for managers, shareholders, creditors, auditors, employees, business valuers, potential investors, and researchers to estimate the company's health condition in the future as an early warning. Prediction models that have been produced are bankruptcy and financial distress prediction models, including the models of Altman, Springate, Zmijewski, and Grover. They provide a certain score as guidance whether the company is experiencing financial distress or not. Meanwhile, an insolvency prediction model that provides a certain number as guidance has not been found, e.g., the prediction made by Chung et al. (2008) and Obradović et al. (2018).

The four models use predictors of liquidity and profitability ratios. In addition, those models, except the Grover model, use debt management ratios. The asset management ratio is also used by those models, except the Zmijewski model. The prediction model guides the categorization of difficulties and financial health of the company. However, the prediction model created by Ohlson, Doumpus, Zopounidis, and Bal, Cheung, and Wu did not provide information on the company's financial distress score (Fachrudin, 2020).

Before a company falls into the financial insolvency stage, it undergoes the stages of initiation and financial insolvency development (Ternovykh \& Durova, 2019). There is an imbalance between the sources of personal funds and credit at the initiation stage of financial insolvency. At the development stage, the company goes through unprofitable periods, showing that financial distress events and insolvency do not occur suddenly. This necessitates a lag between predictor and variables. However, various predictive models do not clearly explain the lag.

A researcher from Serbia developed an insolvency prediction model with predictors in the form of ratios related to liquidity, self-financing, and effectiveness (Obradović et al., 2018). However, the study did not include the equation and indicator scores of the worst insolvency levels and the company's state.

Financial health shows the ability to balance changing conditions in an environment and all business participants (Csikosova et al., 2019). It reflects the company's health in financial aspects, including profitability, liquidity, financing, asset utilization, and market value. The main source of financial health information is the company's financial statements (Ross et al., 2008). A company's financial health can also be determined using the solvency ratio (Ibendahl, 2016). 
Companies with high leverage have a greater likelihood of bankruptcy, while those with low profitability are likely to lose equity (Ibendahl, 2016). Profitability significantly increased the chances of negative corporate equity in the European Union (Mokhova \& Zinecker, 2016).

Indonesia experienced monetary crises in 1997 and 1998. As many as 30 manufacturing companies experienced insolvency in bankruptcy due to large debts. Most of the debts were in foreign currency; thus, when the Indonesian rupiah exchange rate weakened, the debts of these companies increased. Some companies were able to survive with creditors equity stake. However, until now, some manufacturing companies are still experiencing insolvency.

In addition to manufacturing companies, there are also companies in other sectors that experience insolvency as indicated by their negative equity. Since 2019, the Indonesia Stock Exchange has provided special notation for companies with negative equity, amounting to $3.44 \%$ of the total listed companies. The exchange authority considers that negative equity is a warning for investors to make the right decision. Stock analysts recommend avoiding this stock because it is technically considered bankrupt.

This special notation is not only useful for local investors. Foreign investors may also have an interest in this sign since there is a large portion of foreign investor ownership on the Indonesia Stock Exchange, especially for scripless shares which includes 45 liquid shares (LQ45), e.g., Bank Central Asia stock can reach 80.2\%, Bank Rakyat Indonesia stock can reach $77.5 \%$, and Bank Mandiri stock can reach $75.5 \%$. In addition to information about negative equity in the year it occurred, predictions of one year and two years before insolvency will also be useful for all investors, including foreign investors.

This study aims to develop an insolvency prediction models with two years and one year before insolvency as an early warning for decision-makers. This prediction model will be made with quite long observational data, specifically for companies experiencing insolvency from 2010 to 2019. The predictors will be in the form of solvency and profitability variables in two years and one year before the insolvency.

In making a prediction model, financial distress is always used as a dependent binary variable with 1 and 0 . The number 1 indicates the status of companies in financial distress, while 0 indicates the other status. This study uses status 1 for insolvency, which is included in the type of financial distress, and 0 for healthy companies. Therefore, the resulting model can be used for financial health predictions. In case the prediction results show the number 1 , then the company experiences financial distress, if the number 0 , then the company is in a very healthy state. A number between 1 and 0 indicates the health level of a company. This figure was not yet included in the insolvency prediction models from Chung et al. (2008) and Obradović et al. (2018). This study contributes to provide a predictive model for insolvency and financial health based on empirical evidence in Indonesia. It can be beneficial to shareholders, potential investors, creditors, suppliers, government, managers, employees, auditors, and valuers in decision making. The resulted model may be applied in other countries which have the same characteristics as companies in Indonesia.

\section{Literature Review}

\section{Financial Distress}

Financial distress, default, and bankruptcy are some stages of the lifecycle of firms; other than birth, growth, and maturity (Koh et al., 2015). Financial difficulties begin when the company cannot meet the payment schedule or where cash flow projections indicate that the company cannot immediately meet its obligations. There are five types of financial difficulties, namely: economic and business failure, technical insolvency, insolvency in bankruptcy, and legal bankruptcy. In economic failure, the company's revenue cannot cover the total expenses, including capital cost. However, the company may continue its operations as long as the creditor is willing to provide capital, and the owner is willing to accept a rate of return below the market value. Business failure is a situation where operations are stopped due to creditors' losses. In technical insolvency, the company experiences temporary liquidity shortages but still survives, although it can also be an early indicator of economic failure. Insolvency in bankruptcy is a situation where the book value of debt exceeds the market value of assets. Legal bankruptcy is bankruptcy relates to legal conditions.

Businesses in technical bankruptcy experience financial distress, losing all equity, including negative equity (Urionabarrenetxea et al., 2016). Companies with financial distress usually accumulate high negative retained earnings, causing the book value of equity to be negative. Corporate financial distress forecasts are important for investors, companies, and regulatory authorities (Shen et al., 2020)

\section{Historical Background of Financial Distress Prediction Models}

The first pioneer to develop a parametric statistical model to predict the financial distress of a company using information in the financial statements by applying univariate statistics was Beaver in 1966. Furthermore, in 1968, Altman also made a significant contribution to the development of a model for predicting bankruptcy in 
manufacturing companies using multivariate discriminant analysis, in which this model produces a Z-Score value. In 1977, this model was redeveloped for manufacturing and retail companies using the same analysis. The financial ratios used to predict bankruptcy are working capital to total assets, retained earnings to total assets, earnings before interest and taxes to total assets, book value equity to book value of total liabilities, and sales/total assets. This model produces a Revised Z-score (Altman et al., 1977). If the score $<1.23$, the company has the potential to go bankrupt; if the score is between 1.23 and 2.9, it is classified as a gray area; while a score $>2.9$, it is classified as not having the potential for bankruptcy. Altman's model has a classification accuracy of $90 \%$.

Springate (1978) developed the Altman model using 19 popular financial ratios to 40 large Canadian companies and obtained an accuracy rate of $92.5 \%$. This model produces 4 significant financial ratios, namely: working capital to total assets, earnings before interest and taxes to total assets, net income before taxes to current liabilities, and sales to total assets. This model produces a Springate Z-score. If the value is smaller than 0.862 , the company is predicted to go bankrupt; however, if the score is greater than 0.862 , the company is predicted not to go bankrupt.

Zmijewski (1984) conducted a probit analysis to predict company bankruptcy. The model can be applied universally across industries. The financial ratios used to predict are net income to total assets; total debt to total assets, and current assets/current liabilities. This model will produce the number $\mathrm{b} *$. If $\mathrm{b} *>0$, the company is predicted to go bankrupt, whereas if $\mathrm{b} *<0$, the company is predicted not to go bankrupt. The accuracy of this model is $99 \%$.

Grover (2003) also tested company bankruptcy with a predictor in the form of a ratio including working capital to total assets, earning before interest and taxes to total assets, and net income to total assets. This prediction model generates a $Z$ number. If $Z<=-0.02$, the company is categorized as bankrupt; and if $Z>=0.01$, the company is categorized as not bankrupt.

The model predicts financial distress with the bankruptcy type, while Chung et al. (2008) dan Obradović et al. (2018) predicted financial distress with the insolvency type. Chung et al. (2008) used the Multivariate Discriminant Analysis and Artificial Neural Network for Finance Industry companies in New Zealand. Insolvency predictors found were working capital to total assets, retained earnings to total assets, EBIT to total assets, and market value of equity to total liabilities. This model has a prediction accuracy of $62 \%$. Obradović et al. (2018) predicts company insolvency by using logistic regression. He produced a prediction model with a predictor in the form of the ratio of Net Working Capital to Total Assets, Ratio of Self-Financing, Working Capital Turnover Ratio, Effectiveness of Total Business Operations, and Net Cash Inflow (Outflow) from Regular Activities to Total Assets. Both of these models do not mention a score that indicates the company is classified as insolvency or healthy.

\section{Leverage}

The use of debt is less costly than equity; thus, it increases the rate of return, earnings per share, and dividend per share but it is riskier to the company. At hard times and not sufficient operating income to cover interest charges, equity holders have to make up the shortfall or go bankrupt. Financial leverage is the use of debt in financing a company, which increases the risk of the company's equity holders (Brown et al., 2008).

The use of leverage can deduct company taxes due to interest and finance costs, which are recognized as expenses in calculating profit before tax. In a difficult economic situation, these burdens may not be covered by the declining revenue. For this reason, the use of leverage lowers the company's profits. Otherwise, companies that become more profitable tend to reduce leverage (Demirgüç-Kunt et al., 2020).

The total liabilities to total assets ratio is the portion of the solvency ratio showing the percentage of borrowed funds used to increase company assets (Subačienè \& Villis, 2010). It is also called the debt ratio (Brigham \& Daves, 2014). stated that the solvency ratio assesses the amount of used debt capital to determine whether or not a company can meet its long-term obligations.

\section{Equity}

Equity is the difference between a company's assets and liabilities. It describes capital received from investors and retained earnings recorded on the balance sheet (Brown et al., 2008). Negative equity shows that the company's liabilities are greater than the total assets, meaning shareholders' net worth is a deficit. Negative equities are caused by accumulated losses from prior periods, leveraged buyouts, severely depreciated currency rates, or substantial adjustments to intangible property (Mokhova \& Zinecker, 2016). Therefore, the company's ROA in the previous years may influence its equity in the future, both negatively and positively. Companies with negative equity often have poor performance, showing indicators of financial distress with insolvency in bankruptcy.

\section{Leverage, Profitability, Liquidity, and Assets Management Ratio}

Financial leverage may be the most important predictor of corporate distress (Cathcart et al., 2020). The financial distress prediction models with leverage ratio in the form of total liabilities to total assets (TLTA) have been used 
by several researchers (Gombola et al., 1987; Ohlson, 1980; Theodossiou et al., 2006). Return on assets (ROA) is a profitability ratio that measures the efficiency of a company in asset utilization. It determines how efficient a company manager is in managing operations. Financial distress prediction models with predictor of profitability ratio in the form of return on assets have also been widely used (Beaver, 1966; Gombola et al., 1987; Lo, 1986; Ohlson, 1980), retained earning to total assets and earning before interest and taxes to total assets (Altman et al., 1977). Liquidity ratios have also been used to predict financial distress, such as working capital to total assets. In addition, there are also asset management ratio such as sales to total assets (Altman et al., 1977).

\section{Research Method}

\section{Sample Design}

The population of this research are the listed companies on the Indonesia Stock Exchange. The study used a sample consisting of 216 companies with negative equity from 2010 to 2019. The year in which the company has negative equity is called year t. The same number of companies were also used for comparison purposes. The companies for comparison were sought in the same sector but with positive equity. However, due to the existence of the outlier data, the number of analysis units are 424 companies, i.e., 208 companies with negative equity and 216 companies with positive equity.

\section{Variables}

The variables of this study include independent variable and dependent variables.

The independent variable $(\mathrm{Y})$ is company status in which the values are:

$1=$ Companies that experience insolvency indicated by negative equity

$0=$ Companies that do not experience an insolvency as indicated by positive equity/health company

\section{Dependent variable (covariates)}

The independent variables used are the ratio of Total Liabilities to Total Assets $\left(\mathrm{X}_{1}\right)$, Return on Assets $\left(\mathrm{X}_{2}\right)$, Working Capital to Total Assets $\left(\mathrm{X}_{3}\right)$, Retained Earning to Total Assets $\left(\mathrm{X}_{4}\right)$, Sales to Total Assets $\left(\mathrm{X}_{5}\right)$, and Earning Before Interest and Taxes to Total Assets $\left(\mathrm{X}_{6}\right)$ in two years and one year before financial distress ( $\mathrm{t}-2$ and $\left.\mathrm{t}-1\right)$.

\section{Binary regression model}

$y_{1 t}=a+b_{1} x_{1 i t-n}+b_{2} x_{2 i t-n}+\ldots+b_{6} x_{6 i t-n}+\mu$

Descended into logistics distribution function

$P_{\text {it }}=1 /\left[1+\exp \left(a+b_{1} x_{1 i t}+b_{2} x_{2 i t}+\ldots b_{6} x_{6 i t}+\right)\right]$

$\mathrm{P}_{\mathrm{it}}=$ insolvent probability with value is between 0 and 1

The logistics distribution function can be simplified into:

$\mathrm{P}_{\mathrm{it}}=1 /\left[1+2.718^{-\left(\mathrm{a}+\mathrm{b}_{1} x_{1 \mathrm{it}}+\mathrm{b}_{2} \times_{2 i \mathrm{t}}+\ldots+\mathrm{b}_{6} \mathrm{x}_{6 \mathrm{it}}\right]}\right.$

\section{Results and Discussion}

The test using the six proposed dependent variables has resulted in an unfit model. The ratios of working capital to total assets, retained earning to total assets, sales to total assets, and earning before interest and taxes to total assets do not significantly affect the probability of financial distress so that they are excluded from the model. Furthermore, the test is carried out using dependent variables in the form of Total Liabilities to Total Assets $\left(\mathrm{X}_{1}\right)$ and Return on Assets $\left(\mathrm{X}_{2}\right)$ only. The results of the study are presented in descriptive and inference statistics in the form of logistic regression.

\section{Descriptive Statistics}

Table 1 shows that in solvent companies, TLTA of two years (TLTA-2) and one year before observation (TLTA-1) was relatively stable, as its ROA. However, in insolvent companies, there was an increase in TLTA from t-2 to t-1, accompanied by a decrease in ROA. From the observations of the mean numbers presented, increasing leverage in insolvent companies is inversely proportional to profitability.

In this case, it can be seen that the characteristics of insolvent companies in Indonesia shows that the closer to year $\mathrm{t}$, the TLTA increases and the ROA decreases. This means that these total liabilities have not been able to leverage net income, instead burdening the company because of its large finance cost. 
Table 1. Descriptive Statistics of Variables Used

\begin{tabular}{clcccc}
\hline & \multicolumn{2}{c}{ Insolvent Companies } & \multicolumn{2}{c}{ Solvent Companies (Health Companies) } \\
\cline { 3 - 5 } & & TLTA & ROA & TLTA & ROA \\
\hline \multirow{4}{*}{ t-2 } & Minimum & 0.05 & -358.3 & 0.00 & 59.92 \\
& Maximum & 10.12 & 219.2 & 0.89 & 7.18 \\
& Mean & 1.90 & -12.24 & 0.43 & 7.63 \\
& Std. Deviation & 1.70 & 41.23 & 0.22 & 0.02 \\
& Minimum & 0.28 & -208.52 & 0.00 & 36.99 \\
$\mathrm{t}-1$ & Maximum & 20.71 & 319.20 & 0.88 & 6.66 \\
& Mean & 2.28 & -13.71 & 0.42 & 6.30 \\
\hline
\end{tabular}

Note: This table provides the descriptive statistics for Insolvent Companies and Solvent Companies in the 2 years before $(\mathrm{t}-2)$ and 1 year before $(\mathrm{t}-1)$ the occurrence of insolvency

\section{Logistic Regression Test Results}

The study conducted 24 runs of data from 2010 to 2019 and combined data for prediction of two years and one year before insolvency. The test results are shown in Table 2.

\section{Model Coefficients Omnibus Test}

Omnibus test statistics measure the overall model fit. It uses a chi-square test equivalent to the F-test in linear regression. The null hypothesis is rejected in case the p-value of the omnibus test statistic is smaller than the significance level. Significant test statistics imply that logistic regression can be used to model the data. All models produced in this study have a smaller significance than alpha used (0.05), meaning they are compatible with the data.

\section{Nagelkarke $\mathrm{R}^{2}$}

Nagelkarke $\mathrm{R}^{2}$ explains the variability of independent variables explained by dependent variables. All models produced have high Nagelkarke $R^{2}$ numbers. There are 9 models with a number of 1 .

\section{Hosmer and Lemeshow Test}

The Hosmer-Lemeshow goodness-of-fit statistic assesses the model fit. It compares the predicted values with the actual values of the dependent variable. Numbers which are greater than alpha indicate the model is suitable for further analysis since there is no significant difference between the predicted and the observed classifications. The test results show that all models meet the eligibility criteria based on the Hosmer and Lemeshow test, except model number 21.

\section{-2 Log likelihood}

The number -2LL is also called Deviance, DEV, or D and it compares the observed probability with the predicted probability. The Log-Likelihood value of two models shows that they are compatible with the data. A total of 9 models has a value of 0 and $100 \%$ accuracy, meaning there is no need to add variables. TLTA and ROA are sufficient to predict the insolvency in the future.

\section{Classification Tables}

The classification table measures the prediction accuracy of multivariate logistic regression models. The classification accuracy of the resulted model is very good, with all of them are above $90 \%$.

\section{Prediction Model}

From all the models produced, predictions at 1 year before insolvency have higher accuracy compared to 2 years before insolvency. Prediction models with data per year, from 1 to 22 , show that significant predictors at alpha $5 \%$ are only found in TLTA. On the contrary, ROA does not increase the chances of companies experiencing insolvency.

Table 2 shows that $58.3 \%$ of insolvency cases can be predicted more precisely in the one year than two years. However, the accuracy of predictions in the two years before insolvency was above 90\%, except in 2013, i.e., $89.5 \%$. The best model is chosen based on a significant predictor at the alpha of five percent, in this case, the resulting phi value is 0.000 each. Three models can be good predictors. From all the produced models, predictions at 1 year before insolvency have higher prediction accuracy compared to 2 years before insolvency. 
Table 2. Test Results

\begin{tabular}{|c|c|c|c|c|c|c|c|c|c|c|c|c|}
\hline \multirow{2}{*}{ Model } & \multirow{2}{*}{ Year } & \multirow{2}{*}{ Period } & \multirow{2}{*}{$\mathrm{n}$} & Omnibus Test & Nagelkarke $\mathrm{R}^{2}$ & Hosmer and & $-2 \mathrm{LL}$ & & & Variables & in Equat & \\
\hline & & & & signification & Nagelkarke $\mathrm{K}^{2}$ & Lemeshow Test & $-2 \mathrm{LL}$ & Preaicted Percentage Correct & Variable & $\mathrm{B}$ & Sig & $\operatorname{Exp}(B)$ \\
\hline 1 & 2010 & -2 & 43 & 0.000 & 0.905 & 0.928 & 10.740 & 93.0 & Constant & -13.829 & 0.094 & 0.000 \\
\hline & & & & & & & & & TLTA-2 & 18.026 & 0.091 & 67387282.960 \\
\hline & & & & & & & & & ROA-2 & -0.523 & 0.176 & 0.593 \\
\hline 2 & & -1 & 43 & 0.000 & 1 & 1 & 0 & 100 & Constant & -189.601 & 0.984 & 0.000 \\
\hline & & & & & & & & & TLTA-1 & 245.128 & 0.984 & $2.870 \mathrm{E}+106$ \\
\hline & & & & & & & & & ROA-1 & -6.547 & 0.984 & 0.001 \\
\hline 3 & 2011 & -2 & 40 & 0.000 & 0.938 & 0.998 & 6.656 & 94.9 & Constant & -10.689 & 0.029 & 0.000 \\
\hline & & & & & & & & & TLTA-2 & 15.170 & 0.037 & 3874937.894 \\
\hline & & & & & & & & & ROA-2 & -0.599 & 0.127 & 0.550 \\
\hline 4 & & -1 & 40 & 0.000 & 0.937 & 1.000 & 6.743 & 92.3 & Constant & -36.540 & 0.377 & 0.000 \\
\hline & & & & & & & & & TLTA-1 & 50.508 & 0.383 & $8.615 E+21$ \\
\hline & & & & & & & & & ROA-1 & -0.284 & 0.363 & 0.753 \\
\hline 5 & 2012 & -2 & 36 & 0.000 & 0.752 & 0.086 & 20.002 & 91.7 & Constant & -3.479 & 0.018 & 0.031 \\
\hline & & & & & & & & & TLTA-2 & 4.969 & 0.016 & 143.927 \\
\hline & & & & & & & & & ROA-2 & -0.100 & 0.129 & 0.905 \\
\hline 6 & & -1 & 36 & 0.000 & 1 & 1 & 0.000 & 100 & Constant & -109.195 & 0.982 & 0.000 \\
\hline & & & & & & & & & TLTA-1 & 160.473 & 0.982 & $4.926 \mathrm{E}+69$ \\
\hline & & & & & & & & & ROA-1 & -7.100 & 0.982 & 0.001 \\
\hline 7 & 2013 & -2 & 38 & 0.000 & 0.773 & 0.946 & 19.767 & 89.5 & Constant & -4.719 & 0.077 & 0.009 \\
\hline & & & & & & & & & TLTA-2 & 7.414 & 0.073 & 1659.075 \\
\hline & & & & & & & & & ROA-2 & -0.132 & 0.159 & 0.876 \\
\hline 8 & & -1 & 38 & 0.000 & 0.863 & 0.989 & 13.066 & 94.7 & Constant & -7.225 & 0.013 & 0.001 \\
\hline & & & & & & & & & TLTA-1 & 9.982 & 0.014 & 21624.307 \\
\hline & & & & & & & & & ROA-1 & -0.126 & 0.256 & 0.881 \\
\hline 9 & 2014 & -2 & 44 & 0.000 & 0.894 & 1.000 & 12.151 & 95.5 & Constant & -8.912 & 0.032 & 0.000 \\
\hline & & & & & & & & & TLTA-2 & 11.490 & 0.028 & 97749.100 \\
\hline & & & & & & & & & ROA-2 & -0.248 & 0.107 & 0.780 \\
\hline 10 & & -1 & 44 & 0.000 & 0.911 & 0.992 & 10.397 & 95.5 & Constant & -11.971 & 0.095 & 0.000 \\
\hline & & & & & & & & & TLTA-1 & 14.514 & 0.097 & 2010599.283 \\
\hline & & & & & & & & & ROA-1 & -0.140 & 0.560 & 0.869 \\
\hline 11 & 2015 & -2 & 39 & 0.000 & 0.881 & 0.688 & 11.912 & 97.4 & Constant & -9.714 & 0.042 & 0.000 \\
\hline & & & & & & & & & TLTA-2 & 12.449 & 0.038 & 255085.045 \\
\hline & & & & & & & & & ROA-2 & -0.018 & 0.900 & 0.982 \\
\hline 12 & & -1 & 39 & 0.000 & 1.000 & 1.000 & 0.000 & 100 & Constant & -117.136 & 0.990 & 0.000 \\
\hline & & & & & & & & & TLTA-1 & 130.581 & 0.990 & $5.133 \mathrm{E}+56$ \\
\hline & & & & & & & & & ROA-1 & -0.966 & 0.995 & 0.381 \\
\hline 13 & 2016 & -2 & 51 & 0.000 & 0.786 & 0.934 & 25.286 & 90.2 & Constant & -1.960 & 0.188 & 0.141 \\
\hline & & & & & & & & & TLTA-2 & 3.973 & 0.058 & 53.142 \\
\hline & & & & & & & & & ROA-2 & -0.382 & 0.053 & 0.683 \\
\hline 14 & & -1 & 51 & 0.000 & 1.000 & 1.000 & 0.000 & 100 & Constant & -741.264 & 0.928 & 0.000 \\
\hline & & & & & & & & & TLTA-1 & 1116.884 & 0.928 & \\
\hline & & & & & & & & & ROA-1 & -29.300 & 0.927 & 0.000 \\
\hline 15 & 2017 & -2 & 41 & 0.000 & 0.923 & 0.995 & 8.495 & 92.7 & Constant & -5.764 & 0.160 & 0.003 \\
\hline & & & & & & & & & TLTA-2 & 9.422 & 0.191 & 12361.213 \\
\hline & & & & & & & & & ROA-2 & -0.478 & 0.154 & 0.620 \\
\hline 16 & & -1 & 41 & 0.000 & 1.000 & 1.000 & 0.000 & 100 & Constant & -62.108 & 0.989 & 0000 \\
\hline & & & & & & & & & TLTA-1 & 70.412 & 0.989 & $3.299 \mathrm{E}+30$ \\
\hline & & & & & & & & & ROA-1 & -1.119 & 0.992 & 0.327 \\
\hline 17 & 2018 & -2 & 49 & 0.000 & 1.000 & 1.000 & 0.000 & 100 & Constant & -278.016 & 0.964 & 0.000 \\
\hline & & & & & & & & & TLTA-2 & 361.403 & 0.964 & $9.021 \mathrm{E}+156$ \\
\hline & & & & & & & & & ROA-2 & -5.960 & 0.964 & 0.003 \\
\hline 18 & & -1 & 49 & 0.000 & 1.000 & 1.000 & 0.000 & 100 & Constant & -72.820 & 0.984 & 0.000 \\
\hline & & & & & & & & & TLTA-1 & 85.882 & 0.984 & $1.987 \mathrm{E}+37$ \\
\hline & & & & & & & & & ROA-1 & -1.076 & 0.985 & 0.341 \\
\hline 19 & 2019 & -2 & 43 & 0.000 & 1.000 & 1.000 & 0.000 & 100 & Constant & -104.885 & 0.990 & 0.000 \\
\hline & & & & & & & & & TLTA-2 & 135.374 & 0.990 & $6.198 \mathrm{E}+58$ \\
\hline & & & & & & & & & ROA-2 & -3.581 & 0.997 & 0.028 \\
\hline 20 & & -1 & 43 & 0.000 & 1.000 & 1.000 & 0.000 & 100 & Constant & -76.917 & 0.992 & 0.000 \\
\hline & & & & & & & & & TLTA-1 & 91.828 & 0.991 & $7.593 \mathrm{E}+39$ \\
\hline & & & & & & & & & ROA-1 & -2.383 & 0.998 & 0.092 \\
\hline 21 & 2010-2019 & -2 & 424 & 0.000 & 0.853 & 0.000 & 154.595 & 93.4 & Constant & -6.479 & 0.000 & 0.002 \\
\hline & & & & & & & & & TLTA-2 & 8.916 & 0.000 & 7452.771 \\
\hline & & & & & & & & & ROA-2 & -0.145 & 0.000 & 0.865 \\
\hline 22 & & -1 & 424 & 0.000 & 0.941 & 0.826 & 68.992 & 97.9 & Constant & -10.731 & 0.000 & 0.000 \\
\hline & & & & & & & & & TLTA-1 & 13.651 & 0.000 & 848227.631 \\
\hline & & & & & & & & & ROA-1 & -0.176 & 0.000 & 0.839 \\
\hline 23 & 2010-2019 & -1 and -2 & 424 & 0.000 & 0.951 & 0.990 & 58.217 & $97.6 \%$ & Constant & -11.338 & 0.000 & 0.000 \\
\hline & & & & & & & & & TLTA-2 & 1.684 & 0.310 & 5.385 \\
\hline & & & & & & & & & TLTA-1 & 13.054 & 0.000 & 466853.575 \\
\hline & & & & & & & & & ROA-2 & -0.096 & 0.000 & 0.909 \\
\hline & & & & & & & & & ROA-1 & -0.189 & 0.000 & 0.827 \\
\hline 24 & 2010-2019 & -1 and -2 & 424 & 0.000 & 0.949 & 0.992 & 59.638 & 97.4 & Constant & -11.391 & 0.000 & 0.000 \\
\hline & & & & & & & & & TLTA-1 & 14.775 & 0.000 & 2610825.441 \\
\hline & & & & & & & & & ROA-2 & -0.079 & 0.000 & 0.924 \\
\hline & & & & & & & & & ROA-1 & -0.191 & 0.000 & 0.827 \\
\hline
\end{tabular}

Note: Model 1 shows prediction of insolvency using predictors of 2 years before the insolvency in 2010. Model 2 shows predictions of insolvency using predictors 1 year before the insolvency in 2010, and so on until model 20. Model 21- 24 show the prediction of insolvency using predictors 2 years and 1 year before the insolvency from 2010 to 2019 .

Prediction models with data from model 1 to 22 each year show that significant predictors at alpha 5\% are only TLTA. ROA does not increase the chances of companies experiencing insolvency. The best model for insolvency prediction in the 2 years before insolvency is derived from model number 21 . The best model insolvency for prediction in the previous year is derived by model number 22, with the logistic distribution function as follows. The best model for 2 years before and one year before insolvency prediction is derived from model number 24 . The last model is the comprehensive model resulted in this study because it is able to predict with data one year and two years before insolvency. If P produces the number of 1, the company may suffer insolvency. Meanwhile, if it produces the number of 0 , the company is predicted to be healthy. A number between 0 to 1 indicates the health status of a company. 
Based on Exp (B), a decrease in ROA increases the probability of insolvency by less than 1 time. On the contrary, a one-time increase in TLTA may increase the probability of insolvency in a thousand times. In model number 21, a decrease in ROA of 1 time increases probability of insolvency in the next two years by 0.865 times. An increase in TLTA by 1 time increases the probability of insolvency in the next two years by 7452.77 times. For model number 22, a decrease in ROA by 1 time increases the probability of insolvency in the following year by 0.839 times. However, a TLTA increase of 1 time will increase probability of insolvency in the following year by $848,227,631$ times. In model number 24 , a decrease in ROA by 1 time in two years before insolvency increases the probability of insolvency by 0.924 times. On the other hand, a decrease in ROA by 1 time in the previous year increases the probability of insolvency by 0.827 times. An increase in TLTA by 1 time in the previous year increases the probability of insolvency by $2,610,825,441$ times. In this model, TLTA of two years before insolvency has no probability to increase insolvency significantly.

Based on model 21, the insolvency prediction model for the 2 years before insolvency is:

$\mathrm{P}_{\mathrm{it}}=1 /\left[1+2.718^{-\left(-6.479+8.916 \mathrm{X}_{1 \mathrm{it}-2}-0.145 \mathrm{X}_{2 \mathrm{it}-2)}\right]}\right.$

Based on model 22, the insolvency prediction model for the 1 year before insolvency is:

$\mathrm{P}_{\mathrm{it}}=1 /\left[1+2.718^{-\left(-10.731+13.651 \mathrm{X}_{1 \mathrm{it}-1}-0.176 \mathrm{X}_{2 \mathrm{it}-1}\right)}\right]$

Based on model 24, the insolvency prediction model for the 2 years and 1 year before insolvency is:

$\mathrm{P}_{\mathrm{it}}=1 /\left[1+2.718^{-\left(-11.391+14.775 \mathrm{x}_{1 \mathrm{it}-1}-0.079 \mathrm{X}_{2 \mathrm{it}-2}-0.191 \mathrm{X}_{2 \mathrm{it}-1}\right)}\right]$

The $\mathrm{P}$ value will range from 0 to 1 . If the $\mathrm{P}$ is 1 , the company is likely to go insolvent in the following year(s). If the $\mathrm{P}$ is 0 , it can be predicted that the company will be very healthy in the following year(s). A number between 0 and 1 indicates the level of financial health of the company.

\section{Discussion}

This research produced various insolvency prediction models to estimate the level of the financial health of companies. Insolvent probability or $\mathrm{P}_{\text {it }}$ generated by incorporating TLTA and ROA from predicted companies is a warning to the decision-maker. For almost insolvent companies, managers may work out their sustainability by restructuring their debt.

From twenty-four prediction models, TLTA always predicts the probability of insolvency significantly at alpha five percent. This is in line with Ternovykh and Durova (2019) stating that the beginning of insolvency is indicated in an imbalance between sources of personal funds and credit. Appropriate debt management, income, and expenditure synchronization to secure short-term payments are very important to reduce insolvency risk. Therefore, when a company's TLTA is not safe, good debt management is needed immediately. A firm's lower dependence on debt and its financial stability in the long run are likely more important factors with respect to firm survival than its strictly profit-making strategy which is indicated through profit-linked indicators (Baumöhl et al., 2019).

Based on the prediction model from 2010 - 2019, TLTA and ROA predict the probability of insolvency. The company's ROA in the two years and one year before insolvency can increase the accuracy of prediction. This finding is in line with the record in accounting science stating that when a company's profitability decreases, retained earnings reduce, resulting in equity decrease. Companies with higher leverage ratios and worse performance need a creditor arrangement for reorganization (Ayadi et al., 2017).

In this study, other financial ratios cannot be included because they can make the model unfit, determined from the initial data trials. This is reinforced from the 9 models' results with a value of -2LL of 0 and $100 \%$ accuracy, meaning that TLTA and ROA predictors are sufficient to predict insolvency. It is recommended for future studies to advance this prediction model by using predictors from the very previous years, such as at $\mathrm{t}-5$, $\mathrm{t}-4$, and $\mathrm{t}-3$. This makes the anticipation step faster.

Financial distress conditions in Indonesia are different from conditions in other countries, e.g., Altman, Springate, Zmijewski, and Grover's research; thus, liquidity ratios and asset management ratios cannot be included in the model. Financial distress in Indonesia occurs more due to the use of large liabilities. Neglect, fraud, economic, experience, and strategy problems found in Indonesia companies cause them to be burdened by these liabilities which eventually cause the company to become insolvent.

\section{Conclusions}

This study produced 3 models with predictors in the form of TLTA and ROA in the previous year and two years before insolvency. These models have high prediction accuracy, 93.4\%, 97.9\%, and 97.4\%, respectively. Based on annual data, long-term models with projectors one and two years before insolvency were obtained. 
The theoretical implication of this study is that it produced an insolvency prediction model resulting in a measurable score to determine the health level of a company. The practical implication is that by knowing the health score of a company based on the results of this study, managers and employees will be able to make decisions to improve company performance; shareholders and creditors will be able to encourage the company to perform better; auditors and business valuers will be able to consider company risk and company sustainability; and potential investors will be able to consider whether they will provide funding for this company or not. It is recommended for future research to make predictive models with predictors from longer times, e.g., t-3, t-4, and t-5.

\section{References}

Altman, E. I., Haldeman, R. G., \& Narayanan, P. (1977). ZETATM analysis A new model to identify bankruptcy risk of corporations. Journal of Banking \& Finance, 1(1), 29-54.

Ayadi, M. A., Lazrak, S., \& Welch, R. (2017). Determinants of bankruptcy regime choice for Canadian public firms. Research in International Business and Finance, 42, 61-172.

Baumöhl, E., Iwasaki, I., \& Kočenda, E. (2019). Institutions and determinants of firm survival in European emerging markets. Journal of Corporate Finance, 58, 431-453.

Baxter, R. A., Gawler, M., \& Ang, R. (2007). Predictive Model of Insolvency Risk for Australian Corporations. Proceedings of the Sixth Australasian Data Mining Conference, 21-28.

Beaver, W. H. (1966). Financial Ratios As Predictors of Failure. Journal of Accounting Research, 4, 71-111.

Brigham, E. F., \& Daves, P. R. (2014). Intermediate Financial Management (12th ed.). Cengage Learning.

Brown, S. J., Lajbcygier, P., \& Li, B. (2008). Going negative: What to do with negative book equity stocks. The Journal of Portfolio Management, 35(1), 95-102.

Cathcart, L., Dufour, A., Rossi, L., \& Varotto, S. (2020). The differential impact of leverage on the default risk of small and large firm. Journal of Corporate Finance, 60. https://doi.org/10.1016/j.jcorpfin.2019.101541

Chung, K.-C., Tan, S. S., \& Holdsworth, D. K. (2008). Insolvency prediction model using multivariate discriminant analysis and artificial neural network for the finance industry in New Zealand. International Journal of Business and Management, 3(1), 19-29.

Csikosova, A., Janoskova, M., \& Culkova, K. (2019). Limitation of financial health prediction in companies from post-communist countries. Journal of Risk and Financial Management, 12(1), 1-14.

Demirgüç-Kunt, A., Peria, M. S. M., \& Tressel, T. (2020). The global financial crisis and the capital structure of firms: Was the impact more severe among SMEs and non-listed firms? Journal of Corporate Finance, 60. https://doi.org/10.1016/j.jcorpfin.2019.101514

Fachrudin, K. A. (2020). The Relationship between Financial Distress and Financial Health Prediction Model: A Study in Public Manufacturing Companies Listed on Indonesia Stock Exchange (IDX). Jurnal Akuntansi Dan Keuangan, 22(1), 18-27.

Gombola, M. J., Haskins, M. E., Ketz, J. E., \& Williams, D. D. (1987). Cash flow in bankruptcy prediction. Financial Management, 16(4), 55-65.

Grover, J. S. (2003). Validation of cash flow model: A non-bankruptcy approach. Nova Southeastern University.

Ibendahl, G. (2016). Using solvency ratios to predict future profitability. Journal of American Society of Farm Managers and Rural Appraisers, 195-201. https://www.jstor.org/stable/90016049?seq=1

Koh, S., Durand, R. B., Dai, L., \& Chang, M. (2015). Financial distress: Lifecycle and corporate restructuring. Journal of Corporate Finance, 33, 19-33.

Lo, A. W. (1986). Logit versus discriminant analysis: A specification test and application to corporate bankruptcies. Journal of Econometrics, 31(2), 151-178.

Mokhova, N., \& Zinecker, M. (2016). Corporate negative equity: The evidence from the European Union. Acta Universitatis Agriculturae et Silviculturae Mendelianae Brunensis, 64(3), 1021-1036.

Obradović, D. B., Jakšić, D., Rupić, I. B., \& Andrić, M. (2018). Insolvency prediction model of the company: the case of the Republic of Serbia. Economic Research-Ekonomska Istraživanja, 31(1), 139-157.

Ohlson, J. A. (1980). Financial ratios and the probabilistic prediction of bankruptcy. Journal of Accounting Research, 18(1), 109-131. 
Rochon, M. P., Dabrowska, J. F., \& Suwala, R. (2017). Eliminating the effects of the companies insolvency risk: A model approach. World Journal of Applied Economics, 3(1), 21-37.

Ross, S., Westerfield, R. W., \& Jordan, B. D. (2008). Fundamentals of Corporate Finance. McGraw - Hill International Edition.

Shen, F., Liu, Y., Wang, R., \& Zhou, W. (2020). A dynamic financial distress forecast model with multiple forecast results under unbalanced data environment. Knowledge-Based Systems, 192, 105365.

Springate, G. L. V. (1978). Predicting the Possibility of Failure in a Canadian Firm: A Discriminant Analysis. Simon Fraser University.

Subačienè, R., \& Villis, L. (2010). A system of analysis of the total liabilities to total assets ratio. Ekonomika, 18(2), $120-129$.

Ternovykh, E. V., \& Durova, L. V. (2019). Establishment of the differentiated economic mechanism of company bankruptcy prevention as a basic element of sustainable development of rural areas. Earth and Environmental Science 341, 1-7.

Theodossiou, P., Kahya, E., Saidi, R., \& Philippatos, G. (2006). Financial distress and corporate acquisitions: Further empirical evidence. Journal of Business Finance \& Accounting, 23(5-6), 699-719.

Urionabarrenetxea, S., San-Jose, L., \& Retolaza, J.-L. (2016). Negative equity companies in Europe: Theory and evidence. Business: Theory and Practice, 17(4), 307-316.

Zmijewski, M. E. (1984). Essay on Corporate Bankruptcy. State University of New York. 